Article

\title{
Experimental and Economic Analysis of a Concentrating Photovoltaic System Applied to Users of Increasing Size
}

\author{
Carlo Renno ${ }^{1, *(\mathbb{D})}$, Alessandro Perone ${ }^{1}$, Diana $\mathrm{D}^{\prime}$ Agostino $^{2} \mathbb{D}$ and Francesco Minichiello ${ }^{2} \mathbb{D}$ \\ 1 Department of Industrial Engineering, University of Salerno, Via Giovanni Paolo II, 132, 84084 Fisciano, Italy; \\ alessandroperone94@gmail.com \\ 2 Department of Industrial Engineering, University of Naples "Federico II", Piazzale Tecchio 80, \\ 80125 Naples, Italy; diana.dagostino@unina.it (D.D.); francesco.minichiello@unina.it (F.M.) \\ * Correspondence: crenno@unisa.it
}

Citation: Renno, C.; Perone, A.; D’Agostino, D.; Minichiello, F. Experimental and Economic Analysis of a Concentrating Photovoltaic System Applied to Users of Increasing Size. Energies 2021, 14, 4968. https://doi.org/10.3390/ en14164968

Academic Editor: Paweł Ocłoń

Received: 1 June 2021

Accepted: 10 August 2021

Published: 13 August 2021

Publisher's Note: MDPI stays neutral with regard to jurisdictional claims in published maps and institutional affiliations.

\begin{abstract}
The costs of concentrating photovoltaic (CPV) and concentrating photovoltaic and thermal $(\mathrm{CPV} / \mathrm{T})$ systems are highly reduced in the last years because of their increasing diffusion. The unit power cost also depends on the plant size. Hence, the main aim of this paper is to analyze the feasibility of a CPV/T system adopted for users with increasing sizes located in Salerno (Italy): the house, the hotel, and the food industry. An experimental model was developed for an accurate evaluation of the electrical and thermal powers supplied by the CPV/T system when direct normal irradiation (DNI) and environmental temperature vary. A modular configuration of a line-focus $\mathrm{CPV} / \mathrm{T}$ system was sized to match the electrical and thermal loads of each user. The current economic results, together with a forecast till the year 2025, were discussed. In 2025, for the same CPV system adopted for the domestic user, the net present value (NPVs) are expected to increase by $6.7 \%$ and $13 \%$ in pessimistic and optimistic scenarios, respectively, with reductions of its discounted payback period (DPBP) of $16 \%$ and $30 \%$. For the same CPV systems adopted for the other two users, the NPVs are expected to increase by about $4.2 \%$ and $8.4 \%$ in pessimistic and optimistic scenarios, respectively, with decreases of its DPBP of $14 \%$ and $27 \%$.
\end{abstract}

Keywords: CPV/T system; users of different sizes; experimental model; energy and economic analysis

\section{Introduction}

The population growth and the industrial evolution lead to an increasing worldwide energy consumption [1]. However, the great dependency on fossil fuels [2], which are readily available and commonly used to satisfy the world energy demand [3], determines increasingly worrying climate changes, such as global warming, air pollution, and acid rain [4]. Therefore, there is an urgent need for the development of renewable energy technologies to deal with political, economical, and environmental challenges that are involved in the electrical energy production [5]. Among the several possibilities, solar energy [6] is the most promising source for the clean energy generation because of several reasons. In fact, solar energy is the most abundant renewable energy source [7] and is not exhaustible, giving solid and increasing output efficiencies in comparison with other sources of energy [8]. Moreover, solar energy can be simultaneously converted into different energy vectors [9]. For this purpose, the photovoltaic and thermal (PV/T) systems [10] can simultaneously produce electrical and thermal energy. An effective way to increase their energy and economical performances, is to adopt concentrating photovoltaic (CPV) or concentrating photovoltaic and thermal (CPV/T) systems [11]. These systems use optical devices such as mirrors or lenses which are able to convey solar radiation on smaller multi-junction (MJ) cells and to obtain higher electrical power due to their higher electrical conversion efficiency [12]. On the other side, the increase of the sunlight concentration leads to an increase of the cell temperature [13]. However, exploiting the heat recovery from solar cells through an active cooling system (CPV/T) [14], it is possible to increase the 
system conversion efficiency by producing simultaneously electric and thermal energy [15]. Even if currently the traditional energy conversion technologies based on the utilization of fossil fuels are often more convenient [16], CPV and CPV / T systems promise excellent results for the generation of clean energy at competitive costs [17].

Recently, the power capacity of CPV systems in the world market is increased, and it is expected to significantly increase in the next years [18]. Together with their diffusion, the costs of CPV systems have undergone a high reduction [19], and it is expected that they will further decrease in the next years, thus leading to a greater convenience with respect to traditional PV systems [20]. It is clear that, because of the scale economies, the unit cost of electrical power for a CPV system decreases when its size increases [21]. Hence, it should be interesting to analyze the feasibility of a CPV/T system adopted for users of increasing size, and this represents the main aim of this paper.

\section{Experimental Plant}

The experimental CPV/T plant, realized at the Applied Thermodynamics Laboratory of University of Salerno [14], is shown in Figure 1.

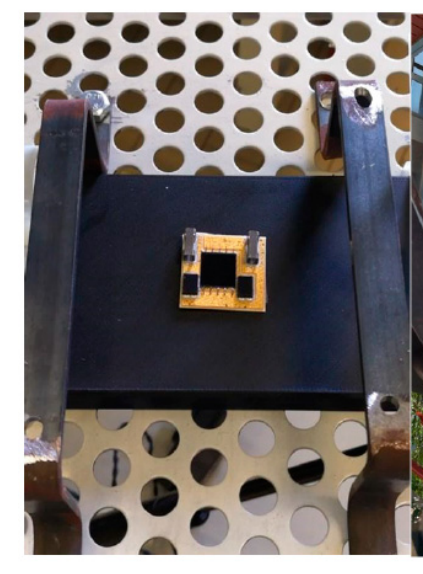

a)

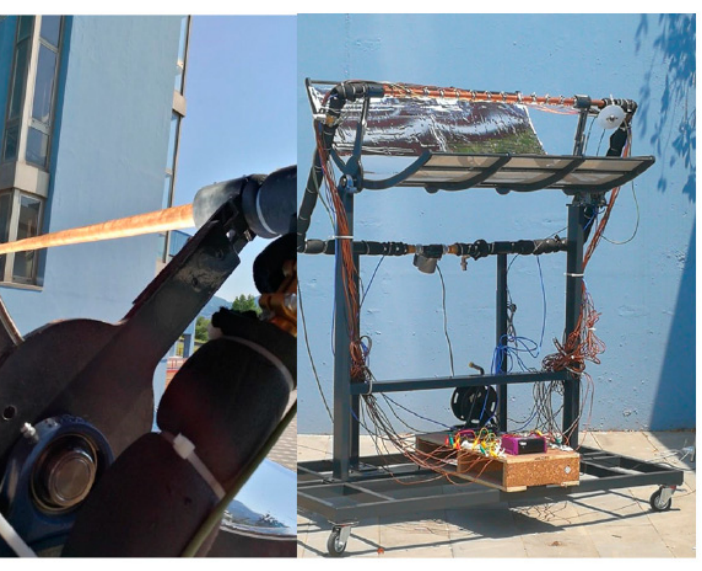

b)

c)

Figure 1. Experimental plant: (a) triple-junction solar cell; (b) cooling fluid circuit; (c) line-focus concentrating photovoltaic and thermal $(\mathrm{CPV} / \mathrm{T})$ system.

It was a line-focus CPV/T system with a reflective optics consisting of a parabolic trough concentrator [14], which focused solar radiation along a tube where triple-junction (TJ) solar cells were located and a refrigerant fluid flows. Sixty TJ cells, with an active area of $1.0 \times 1.0 \mathrm{~cm}^{2}$, were located on a tube with a length of $1.2 \mathrm{~m}$; the TJ cells characteristics are reported in Table 1.

Table 1. Parameters of the triple-junction cell.

\begin{tabular}{cc}
\hline Parameter & Value \\
\hline material & InGaP $/ \mathrm{InGaAs} / \mathrm{Ge}$ \\
dimension & $10 \mathrm{~mm} \times 10 \mathrm{~mm}$ \\
$\mathrm{I}_{\mathrm{SC}}\left(\right.$ at $\left.25^{\circ} \mathrm{C} ; 50 \mathrm{~W} / \mathrm{cm}^{2}\right)$ & $4.49 \mathrm{~A}$ \\
$\mathrm{~V}_{\mathrm{oc}}\left(\right.$ at $\left.25^{\circ} \mathrm{C} ; 50 \mathrm{~W} / \mathrm{cm}^{2}\right)$ & $2.94 \mathrm{~V}$ \\
$\eta_{\mathrm{r}}\left(\right.$ at $\left.25^{\circ} \mathrm{C} ; 50 \mathrm{~W} / \mathrm{cm}^{2}\right)$ & $39.0 \%$ \\
\hline
\end{tabular}

The experimental plant presented a two-axis tracking system able to converge the maximum direct normal irradiance (DNI) on TJ cells by means of two rotation movements. The first rotation movement in the horizontal plane allowed following the sun in the azimuth direction, while the second in the vertical plane followed the sun in the zenithal direction. Moreover, a further degree of freedom of the structure allowed to modify the distance between optics and tube, where the TJ cells were located, varying the concentration 
factor. The main parameters that characterize parabolic optics [14] are their focal lengths on which the size of the focused image depends and the truncation value on which the amount of energy conveyed on the tube depends. Hence, the concentration factor is proportional to the ratio of the two parameters. The maximum value of the optical concentration factor $\left(\mathrm{C}_{\text {opt }}\right)$ measured during the system operation, which corresponds to a proper focal length, was about 90 [14]. PT100 (platinum thermo-resistances with an accuracy of $\pm 0.2{ }^{\circ} \mathrm{C}$ ) were adopted to measure the fluid, cell, and environmental temperatures; a pyrheliometer (accuracy: 2\%) was used to measure the DNI [14]. A maximum power point tracking (MPPT) was linked to the cells, and an acquisition data system (data tracker series DT80; accuracy: $2 \%$ ) was used for the experimental measurements of voltage, current, DNI, and temperatures; the sampling period in the analysis was $15 \mathrm{~s}$.

\section{Experimental Modelling and Economic Analysis}

\subsection{Experimental Modelling}

A correct sizing of a CPV/T system requires an accurate evaluation of its energy performances, when the operating conditions vary [22]. It could be considered a modular configuration to vary the number of modules matching the energy load of a specific user. The experimental CPV/T plant described in the previous section can be considered as a single module. Its electrical power depends on the TJ cells operation temperature and on the concentrated solar radiation $\left(S_{\text {cell }}\right)$ incident on it. $S_{\text {cell }}$ was given by:

$$
\mathrm{S}_{\mathrm{cell}}=\mathrm{DNI} \cdot \mathrm{C}_{\mathrm{opt}}
$$

As for the $\mathrm{TJ}$ cell temperature $\left(\mathrm{T}_{\text {cell }}\right)[23,24]$, which is approximately equal to the refrigerant temperature $\left(\mathrm{T}_{\text {fluid }}\right)$, an experimental relation linking it to the environmental temperature $\left(\mathrm{T}_{\mathrm{env}}\right)$ and to $\mathrm{S}_{\text {cell }}$ was found. It was observed that the increase of $\mathrm{T}_{\text {cell }}$ with respect to $T_{\text {env }}$ increases logarithmically with the concentrated radiation according to the following relation:

$$
\mathrm{T}_{\text {cell }}-\mathrm{T}_{\text {env }}=\mathrm{C} \cdot \ln \mathrm{S}_{\text {cell }}+\mathrm{D},
$$

where the coefficients $C$ and $D$ are experimentally determined.

The electrical power supplied by the module described $\left(\mathrm{P}_{\mathrm{el}, \mathrm{mod}}\right)$ was experimentally monitored in cold winter and hot summer days with different conditions of solar radiation. Data representing different CPV/T system operating conditions were collected. Adopting a black-box modeling approach, a multivariable regression of the measured data, with a significance level $\alpha=0.05$, was adopted [24]. The following relation linking $\mathrm{P}_{\mathrm{el}, \mathrm{mod}}$ to $\mathrm{S}_{\text {cell }}$ and $\mathrm{T}_{\text {cell }}$ was determined:

$$
\mathrm{P}_{\mathrm{el}, \mathrm{mod}}=\mathrm{C} \cdot \mathrm{S}_{\mathrm{cell}}+\mathrm{D} \cdot \frac{1}{\mathrm{~T}_{\mathrm{cell}}},
$$

where coefficients $C$ and $D$ are experimentally evaluated. The validity ranges for the two relations were shown as following:

$$
9.00 \frac{\mathrm{kW}}{\mathrm{m}^{2}}<\mathrm{S}_{\text {cell }}<83.7 \frac{\mathrm{kW}}{\mathrm{m}^{2}} \text { and } 35.0{ }^{\circ} \mathrm{C}<\mathrm{T}_{\text {cell }}<95.0^{\circ} \mathrm{C} .
$$

The values of $\mathrm{P}_{\mathrm{el} \text {,mod }}$ calculated by Equation (3) consider the parasitic current losses generated in the module and the module efficiency that takes into account the coupling in series of the TJ cells along a line where a TJ cell can operate at an efficiency lower than the nominal one.

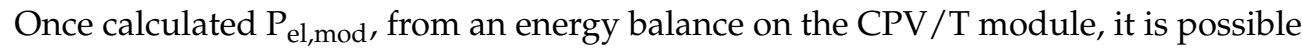
to calculate the recoverable thermal power $\left(Q_{t h, m o d}\right)$ equal to:

$$
\mathrm{Q}_{\text {th,mod }}=\mathrm{S}_{\text {cell }} \cdot \mathrm{A}_{\text {tube }}-\mathrm{P}_{\text {el,mod }}-\mathrm{Q}_{\text {th,loss }}
$$

where $A_{\text {tube }}$ is the area of the tube where $S_{\text {cell }}$ is conveyed, and $Q_{\text {th,loss }}$ represents the thermal losses to the environment. 
The utilization of the recoverable thermal power is strictly dependent on its temperature. Hence, $Q_{\text {th,mod }}$ is divided into two parts:

- $\quad$ Low-temperature thermal power $\left(\mathrm{LTQ}_{\text {th }}\right)$ available at temperatures lower than $40.0{ }^{\circ} \mathrm{C}$, so it is unusable;

- $\quad$ Middle-high-temperature thermal power $\left(\mathrm{MHTQ}_{\text {th }}\right)$ available at temperatures higher than $40.0^{\circ} \mathrm{C}$, which can be used for winter heating $(\mathrm{WH})$ and to produce domestic hot water (DHW).

Therefore, with the values of $\mathrm{T}_{\mathrm{env}}$ and DNI available in [25] for each place and the value of $\mathrm{C}_{\text {opt }}$ for the CPV system defined, it is possible to calculate $\mathrm{T}_{\text {cell }}$ by Equation (2), $P_{\text {el,mod }}$ by Equation (3), and $Q_{\text {th,mod }}$ by Equation (5).

Hence, the electric and thermal powers supplied by a CPV/T system [26] can be calculated as:

$$
\begin{gathered}
\mathrm{P}_{\mathrm{el}, \mathrm{CPV} / \mathrm{T}}=\mathrm{P}_{\mathrm{el}, \bmod } \cdot \mathrm{n}_{\bmod } \cdot \mathrm{f} \cdot \eta_{\mathrm{inv}}, \\
\mathrm{Q}_{\mathrm{th}, \mathrm{CPV} / \mathrm{T}}=\mathrm{Q}_{\mathrm{th}, \bmod } \cdot \mathrm{n}_{\mathrm{mod}},
\end{gathered}
$$

where $P_{\text {el,mod }}$ and $Q_{\text {th,mod }}$ can be calculated by Equations (3) and (5), respectively, $n_{\text {mod }}$ is the number of modules, and $\eta_{\text {inv }}$ is the inverter efficiency. Considering a non-ideal tracking system, a factor equal to 0.9 is considered.

\subsection{Determination of the CPV System Cost}

The cost of a CPV system $\left(\mathrm{C}_{\mathrm{CPV}}\right)$ can be calculated as the product between its peak electrical power $\left(\mathrm{P}_{\mathrm{el}, \mathrm{CPV} \max }\right)$ and the cost per unit of power $\left(\mathrm{c}_{\mathrm{u}, \mathrm{P}}\right)$ :

$$
\mathrm{C}_{\mathrm{CPV}}=\mathrm{c}_{\mathrm{u}, \mathrm{P}} \cdot \mathrm{P}_{\mathrm{el}, \mathrm{CPV} \max }
$$

The CPV unit cost reductions in the years from 2011 to 2019 in Italy are shown in Table 2 [19]; the CPV system is divided into four categories according to the peak electrical power.

Table 2. Reductions of the concentrating photovoltaic (CPV) unit cost ( $€ / W)$ from 2011 to 2019 for four categories with different power sizes [19].

\begin{tabular}{ccccc}
\hline Year & $<\mathbf{1 0}(\mathbf{k W})$ & $\mathbf{1 0 - 1 0 0}(\mathbf{k W})$ & $\mathbf{1 0 0 - 2 5 0} \mathbf{( k W )}$ & $\mathbf{1 0 - 2 0} \mathbf{( M W )}$ \\
\hline 2011 & $6.68 € / \mathrm{W}$ & $4.88 € / \mathrm{W}$ & $4.47 € / \mathrm{W}$ & $2.76 € / \mathrm{W}$ \\
2012 & $5.22 € / \mathrm{W}$ & $4.29 € / \mathrm{W}$ & $3.34 € / \mathrm{W}$ & $1.98 € / \mathrm{W}$ \\
2013 & $4.5 € / \mathrm{W}$ & $3.61 € / \mathrm{W}$ & $2.82 € / \mathrm{W}$ & $1.8 € / \mathrm{W}$ \\
2014 & $3.6 € / \mathrm{W}$ & $3.01 € / \mathrm{W}$ & $2.82 € / \mathrm{W}$ & $1.53 € / \mathrm{W}$ \\
2015 & $3.42 € / \mathrm{W}$ & $2.87 € / \mathrm{W}$ & $2.62 € / \mathrm{W}$ & $1.42 € / \mathrm{W}$ \\
2016 & $3.29 € / \mathrm{W}$ & $2.71 € / \mathrm{W}$ & $2.43 € / \mathrm{W}$ & $1.3 € / \mathrm{W}$ \\
2017 & $3.03 € / \mathrm{W}$ & $2.49 € / \mathrm{W}$ & $2.11 € / \mathrm{W}$ & $1.17 € / \mathrm{W}$ \\
2018 & $2.94 € / \mathrm{W}$ & $2.42 € / \mathrm{W}$ & $2.07 € / \mathrm{W}$ & $1.01 € / \mathrm{W}$ \\
2019 & $2.88 € / \mathrm{W}$ & $2.39 € / \mathrm{W}$ & $2.13 € / \mathrm{W}$ & $1.07 € / \mathrm{W}$ \\
\hline
\end{tabular}

The cost reduction is due to an increasing diffusion of CPV systems during the years. The increase of the CPV power capacity ( $\mathrm{PC}_{\mathrm{CPV}}$ ) during the years from 2011 to 2019, together with two forecasts till 2025 referred to pessimistic and optimistic scenarios, respectively, is shown in Figure 2 [18]. Hence, in 2025, the CPV power capacity in Italy will be equal to $350 \mathrm{MW}$ in a pessimistic scenario and to $800 \mathrm{MW}$ in an optimistic one. By relating the CPV system cost reduction over years reported in Table 2 with the CPV power capacity (PC $\mathrm{CPV}$ ) per year in Figure 2, it is possible to make a forecast on the values of $\mathrm{c}_{\mathrm{u}, \mathrm{P}}$ over the years from 2020 to 2025 in the two scenarios defined. The results have shown that, for each category identified, the unit cost of the electric power supplied by a CPV systems will decrease as a function of the CPV power plant capacity in accordance with the following equation:

$$
\mathrm{c}_{\mathrm{el}}=\gamma \cdot \mathrm{PC}_{\mathrm{CPV}}{ }^{\delta}
$$


where $\mathrm{PC}_{\mathrm{CPV}}$ indicates the installations of $\mathrm{CPV}$ power plant capacity, and $\gamma$ and $\delta$ are two parameters determined for each category.

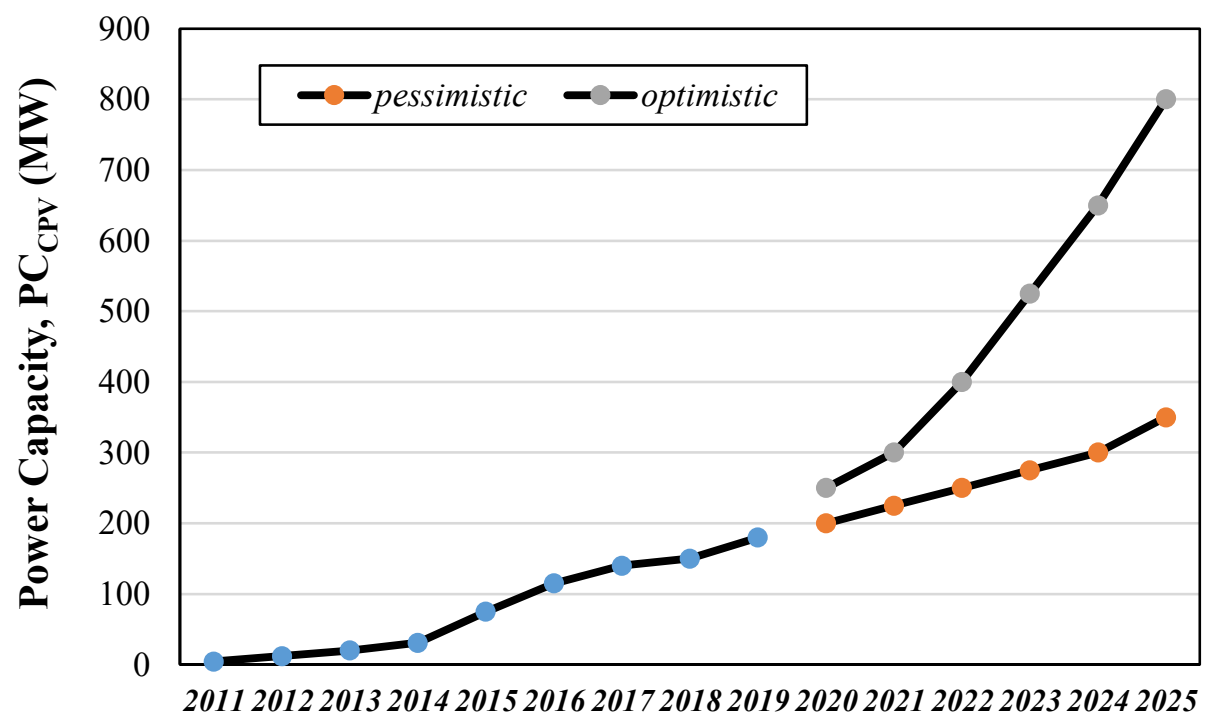

Figure 2. Increase of $\mathrm{PC}_{\mathrm{CPV}}$ during the years 2013-2019 in two possible forecasts, i.e., optimistic and pessimistic scenarios, for the years 2020-2025.

\subsection{Economic Analysis}

Once the monthly electric and thermal loads of a given domestic user are defined, it is possible to calculate the number of modules necessary to match the domestic user's needs for each locality chosen. It is clear that by increasing the number of modules, the $\mathrm{CPV} / \mathrm{T}$ system electrical and thermal producibilities also increase. However, if the number of modules is excessively high, the producibility exceeds the energy needs of the user to be powered, thus leading to an oversized system.

The optimal number of modules for each locality can be calculated with the aim of maximizing the profitability of the investment, expressed in terms of net present value (NPV) equal to:

$$
\mathrm{NPV}=-\mathrm{I}_{0}+\sum_{\mathrm{i}=1}^{\mathrm{UL}} \frac{\mathrm{CF}_{\mathrm{i}}}{(1+\mathrm{r})^{\mathrm{i}}},
$$

where $\mathrm{I}_{0}$ is the initial investment, $\mathrm{CF}_{\mathrm{i}}$ is the cash flow for the $\mathrm{i}$-th year, $\mathrm{r}$ is the discount rate, and $\mathrm{UL}$ represents the $\mathrm{CPV}$ system useful life; the initial investment $\mathrm{I}_{0}$ is given by the cost of the CPV system $\left(\mathrm{C}_{\mathrm{CPV}}\right)$, calculated according to Equation (8). The cash flow for the $\mathrm{i}$-th year is given by the sum of the cost savings for the purchase of the electrical and thermal energy needed by the user $\left(\mathrm{CS}_{\mathrm{i}}\right)$ and the gains from the sale of the surplus electrical energy $\left(\mathrm{G}_{\mathrm{i}}\right)$ and can be written as:

$$
\mathrm{CF}_{\mathrm{i}}=\mathrm{CS}_{\mathrm{i}}+\mathrm{G}_{\mathrm{i}}
$$

where the cost savings $\mathrm{CS}_{\mathrm{i}}$ for the i-th year can be calculated as follows:

$$
\mathrm{CS}_{\mathrm{i}}=\sum_{\mathrm{m}=1}^{12} \mathrm{C}_{\mathrm{el}} \cdot \min \left(\mathrm{E}_{\mathrm{el}, \mathrm{CPV} / \mathrm{T}_{\mathrm{m}}} ; \mathrm{E}_{\mathrm{el}, \mathrm{U}_{\mathrm{m}}}\right)+\mathrm{c}_{\mathrm{th}} \cdot \min \left(\mathrm{E}_{\mathrm{th}, \mathrm{CPV} / \mathrm{T}_{\mathrm{m}}} ; \mathrm{E}_{\mathrm{th}, \mathrm{U}_{\mathrm{m}}}\right),
$$

where $\mathrm{c}$ indicates the unit purchase cost of each energy vector, multiplied for the respective monthly shares of the CPV/T system energy producibilities (subscript $\mathrm{CPV} / \mathrm{T}$ ) which do not exceed the user monthly energy needs (subscript $U$ ). As for the evaluation of $c_{t h}$, it is assumed to produce thermal energy by means of a methane boiler.

The gains from the sale of the surplus electrical energy $\left(G_{i}\right)$ are calculated as the product between the monthly energy surplus produced by the CPV/T system and the relative selling price to the energy network $\left(\mathrm{p}_{\mathrm{e}}\right)$ : 


$$
\mathrm{G}_{\mathrm{i}}=\sum_{\mathrm{m}=1}^{12} \mathrm{p}_{\mathrm{e}} \cdot \min \left(0 ; \mathrm{E}_{\mathrm{el}, \mathrm{CPV} / \mathrm{T}_{\mathrm{m}}}-\mathrm{E}_{\mathrm{el}, \mathrm{U}_{\mathrm{m}}}\right) .
$$

The analysis conducted on the NPV allows evaluating the discounted payback period (DPBP). Another index, useful in the investment evaluation, is the profit index (PI) defined as the ratio between NPV and $\mathrm{I}_{0}$ :

$$
\mathrm{PI}=\frac{\mathrm{NPV}}{\mathrm{I}_{0}} .
$$

\section{Results and Discussion}

The main aim of this paper is to analyze the feasibility of CPV systems applied to users of increasing size. Hence, first, the electrical and thermal loads of three different users are defined. A house is chosen as a small-size user. A middle-size user, instead, can be well represented by a hotel. Finally, an industry can be representative of a large-size user.

\subsection{Definition of the Users Load}

In this section, the electrical and thermal loads of the three above-mentioned users are defined (Figure 3). The smallest user is a house of $120 \mathrm{~m}^{2}$ inhabited by 4 persons (Figure 3a). It presents a peak electrical power of $3.3 \mathrm{~kW}$ and generally monthly electrical loads enough constant during the year. As for the thermal loads, they include the thermal energy necessary both for DHW and for WH.

The hotel, representative of a middle-size user, has a constant turnout during the year, except in summer when there is a high reduction in occupancy (Figure 3b). It is characterized by an electrical peak power of about $150 \mathrm{~kW}$; its monthly energy loads depend on the turnout of the guests.

Finally, a food industry is chosen as representative of large-size users (Figure 3c). It occupies an area of about $100,000 \mathrm{~m}^{2}$, of which $25,000 \mathrm{~m}^{2}$ are covered. The production site works $16 \mathrm{~h}$ a day for a total of about 300 days a year and presents an electrical peak power of about 8.5 MW. The electrical loads depend on the production levels linked to fundamental activities, including the use of electrical machinery for the preparation, production, and packaging of foodstuffs. Thermal loads are due to the cooking of semi-finished food, thermal treatments for its stabilization and preservation, and the production of hot water and steam for machinery washing, decontamination, and sterilization.

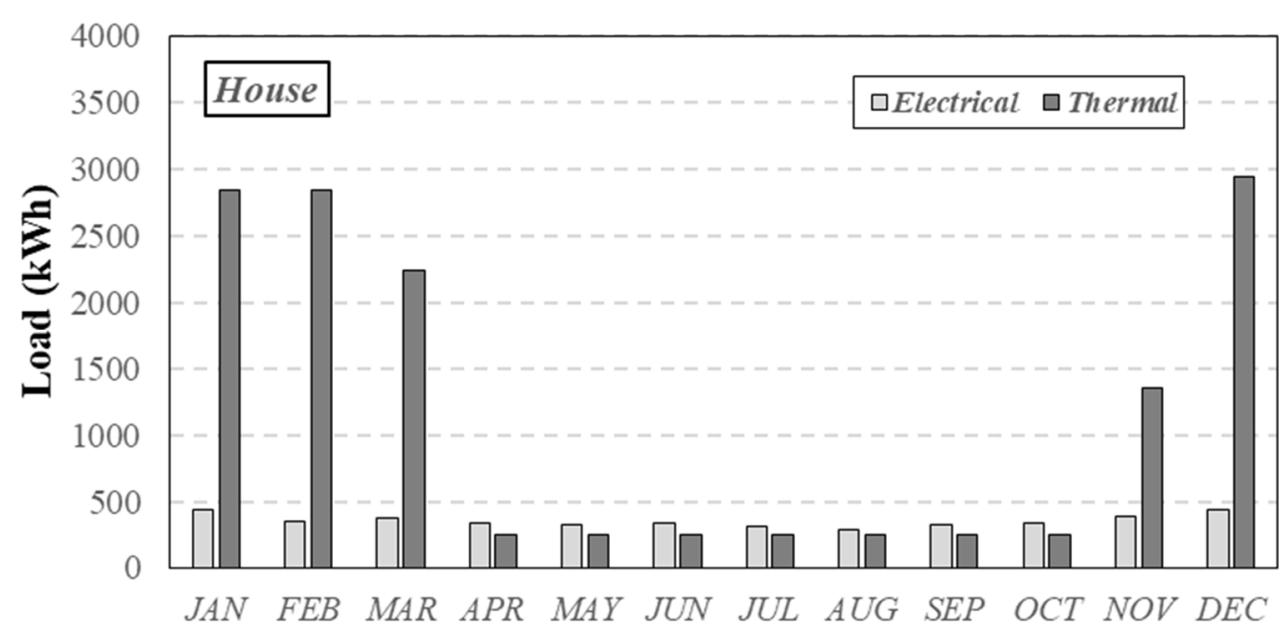

(a)

Figure 3. Cont. 


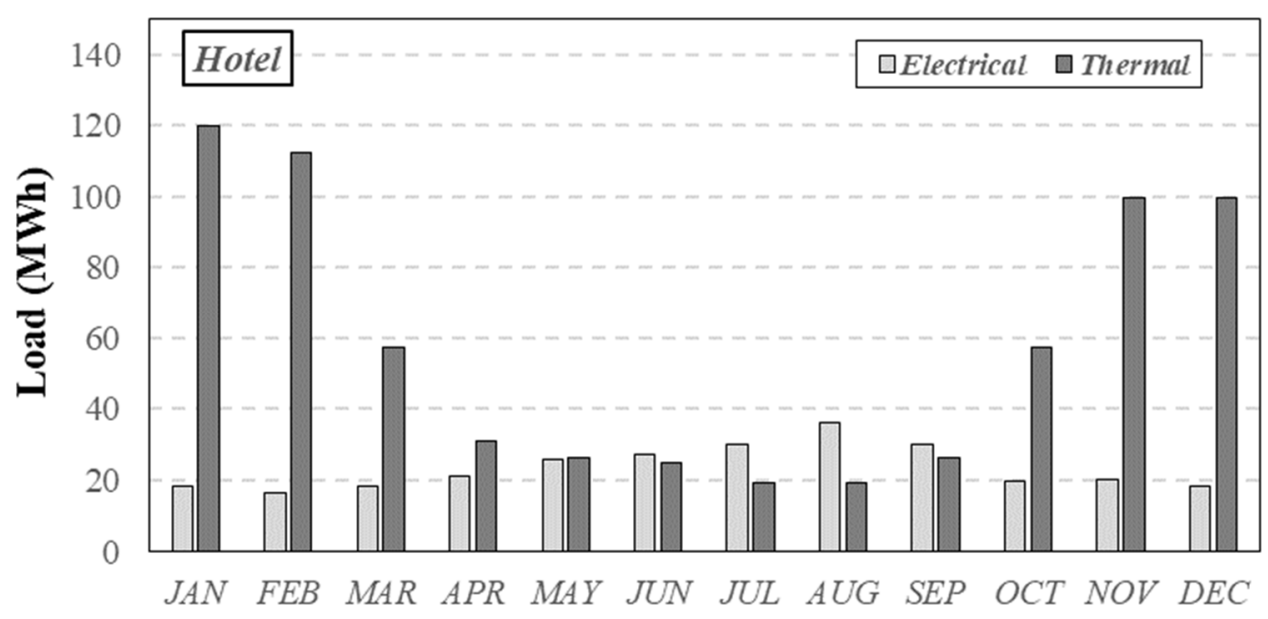

(b)

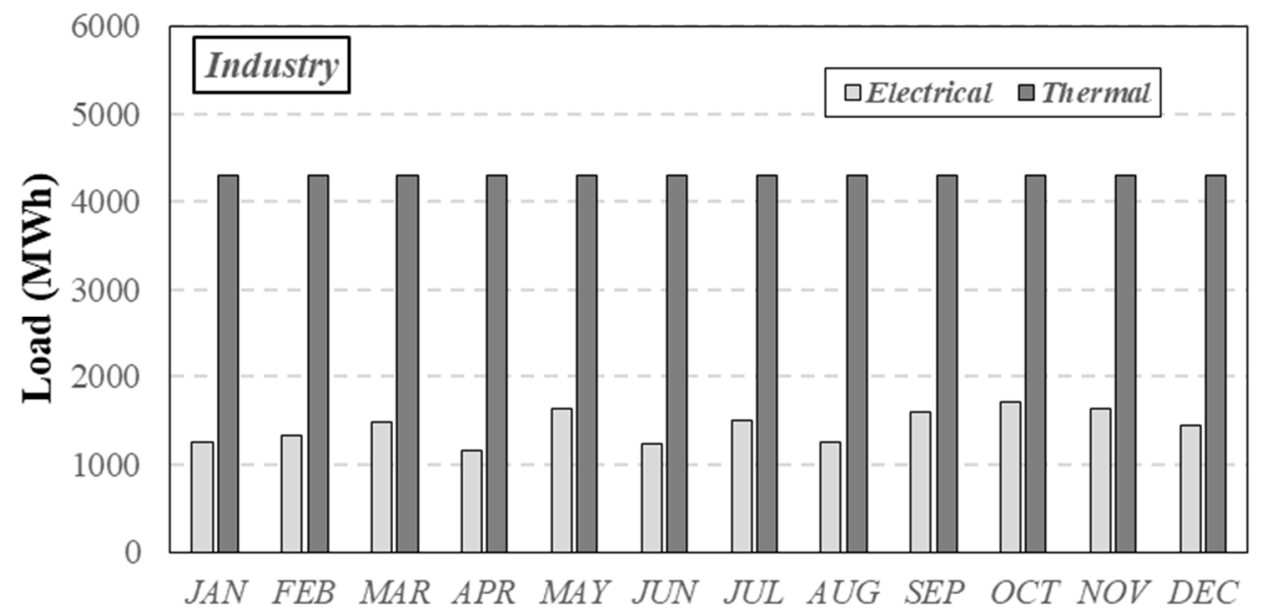

(c)

Figure 3. Electrical and thermal loads of the three users defined: (a) house; (b) hotel; and (c) industry.

\subsection{Results}

In this section, the main results of the feasibility studies concerning the three above defined users are discussed. For an accurate evaluation of the CPV system energy performances during the year, the effective annual hourly distributions of DNI and $\mathrm{T}_{\text {env }}$ in Salerno is considered [25].

For the CPV/T system, the abovementioned experimental plants, with optical concentration factors equal to 90 and $60 \mathrm{TJ}$ cells, were considered as a single module. The coefficients in Equations (2) and (3) for the calculation of $\mathrm{T}_{\text {cell }}$ and $\mathrm{P}_{\text {el,cell }}$ are reported in Table 3 together with the values of $R^{2}$.

Table 3. Values of the coefficients of the experimental equations describing the trends of $T_{\text {cell }}$ and $\mathrm{P}_{\mathrm{el}, \mathrm{cell}}$.

\begin{tabular}{cccccc}
\hline Equation & $\mathbf{A}$ & $\mathbf{B}$ & $\mathbf{C}$ & $\mathbf{D}$ & $\mathbf{R}^{\mathbf{2}}$ \\
\hline$(2)$ & 12.481 & 0.9794 & $/ /$ & $/ /$ & 0.9552 \\
$(3)$ & $/ /$ & $/ /$ & 1.4193 & 500.51 & 0.9479 \\
\hline
\end{tabular}

Because the annual hourly values of $\mathrm{T}_{\mathrm{env}}$ and DNI are available, it is possible to calculate, by means of Equations (6) and (7), the electric $\left(\mathrm{P}_{\mathrm{el}, \mathrm{CPV} / \mathrm{T}}\right)$ and thermal $\left(\mathrm{Q}_{\mathrm{th}, \bmod }\right)$ 
powers supplied by the CPV systems by varying its number of modules. Generally, it could be interesting to analyze the difference between CPV/T system outputs and energy loads of each user on a monthly basis when its number of modules varies. In Figure 4, the number of modules of the CPV/T system is varied to match the electrical loads of each user.

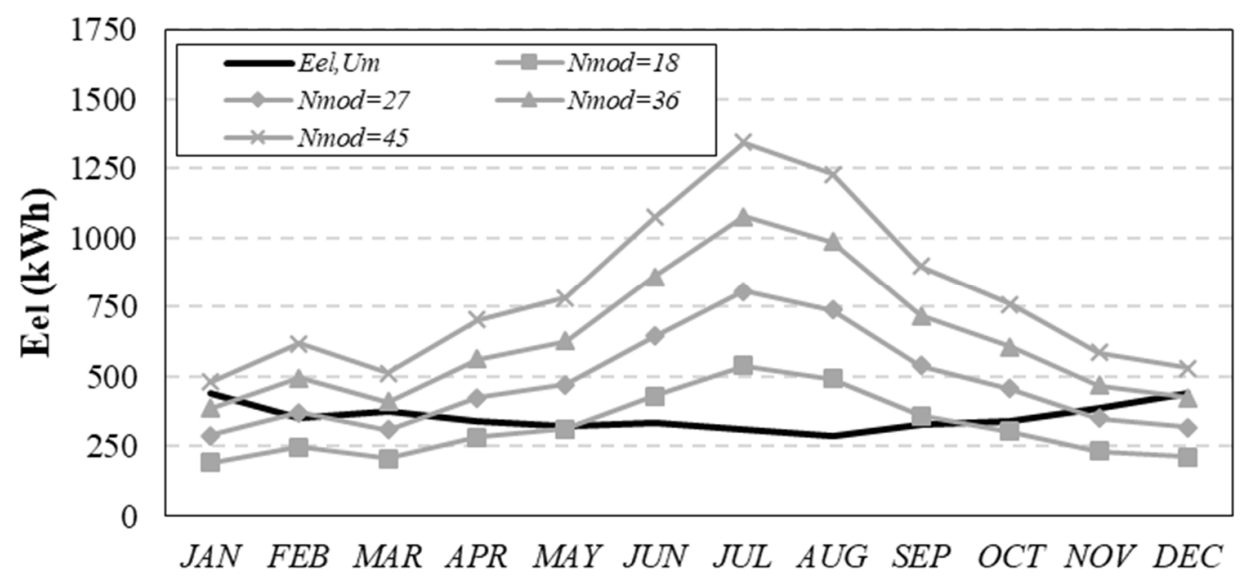

(a)

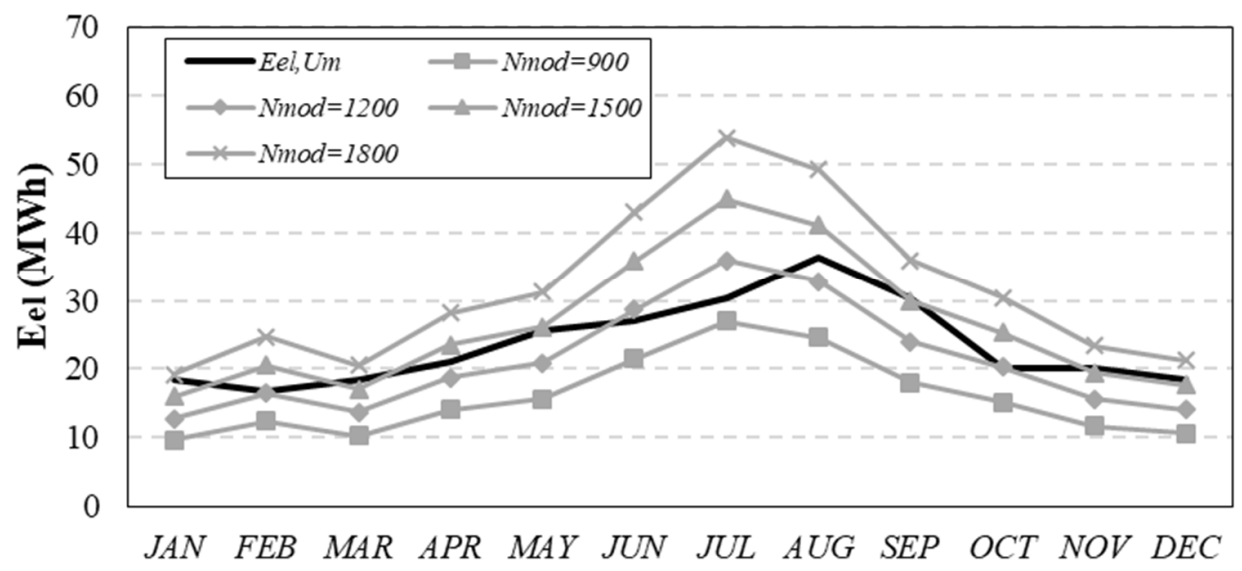

(b)

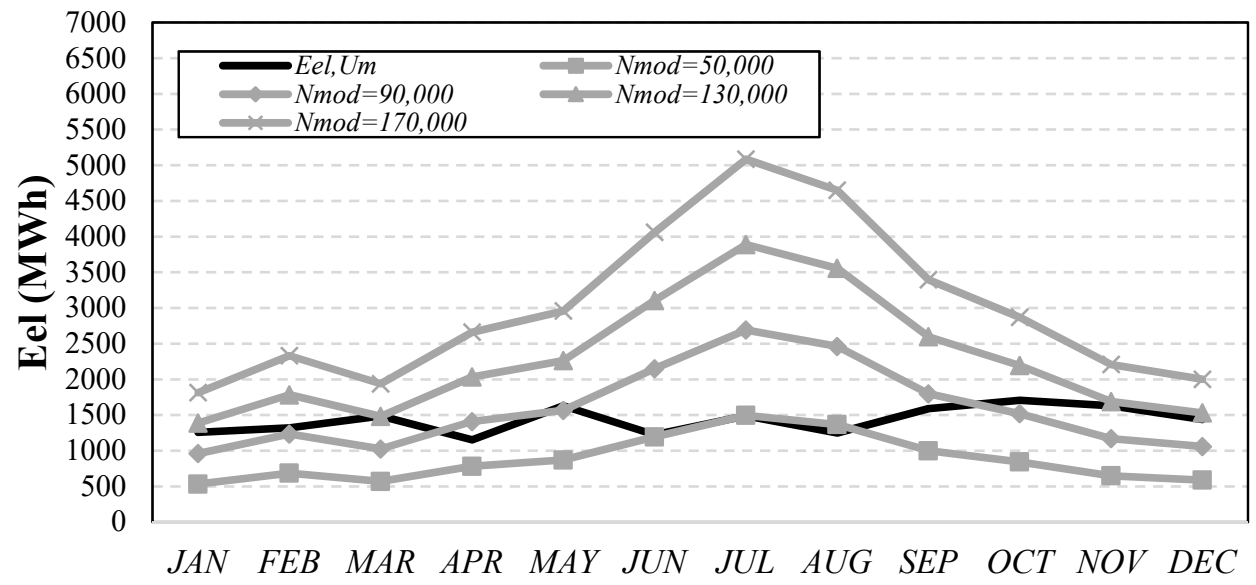

(c)

Figure 4. Difference between the CPV/T system electrical outputs on a monthly basis by varying its number of modules and the electrical loads of the three users: (a) house; (b) hotel; and (c) industry.

As shown, the domestic user presents a monthly electrical load which is not extremely variable during the year. Hence, in the summer period, the CPV/T system producibility 
always exceeds the user's loads for the numbers of modules considered. Thirty-six modules would be sufficient to satisfy the electrical energy needs almost all over the year. On the other hand, the hotel presents a greater variability in its monthly energy needs, since they depend on the turnout of the guests. The CPV/T system electrical producibility better fits the user monthly loads, and 1500 modules allow satisfying them almost every month. The electrical loads of the industrial user, instead, are constant enough during the year. Hence, in this case, in the summer period, there is an overproduction of electrical energy. Very high energy needs require 130,000 modules to be satisfied.

In Figure 5, the same analysis is performed from a thermal point of view. For each user, the same number of modules of the electrical analysis is considered. In correspondence of the number of modules considered, the CPV/T system thermal producibility exceeds the loads of each user almost all over the year.

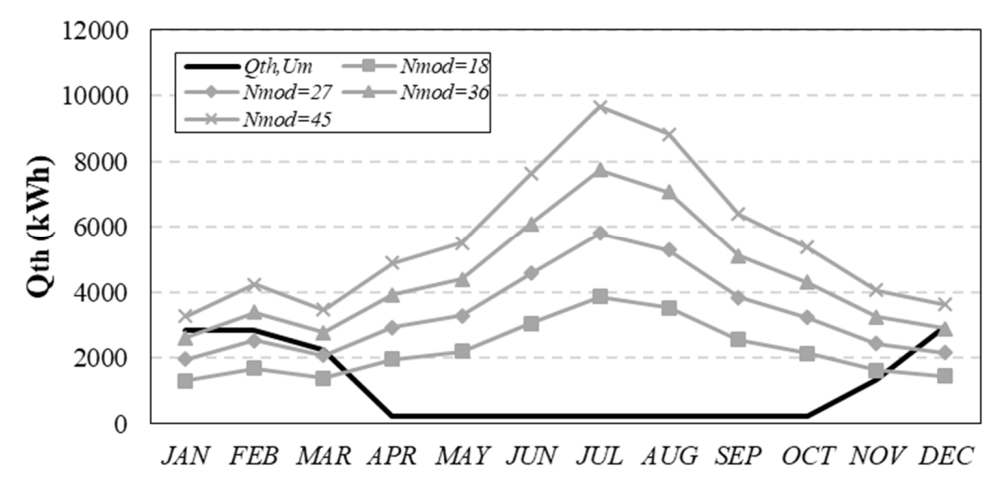

(a)

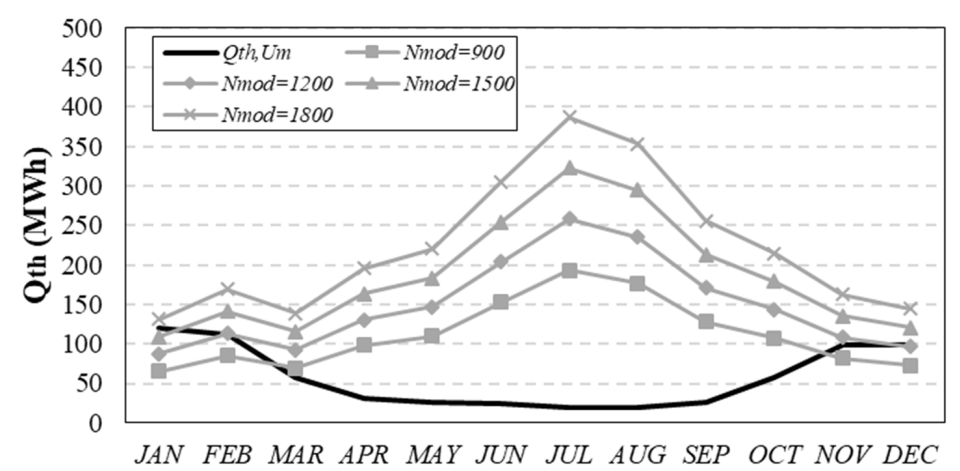

(b)

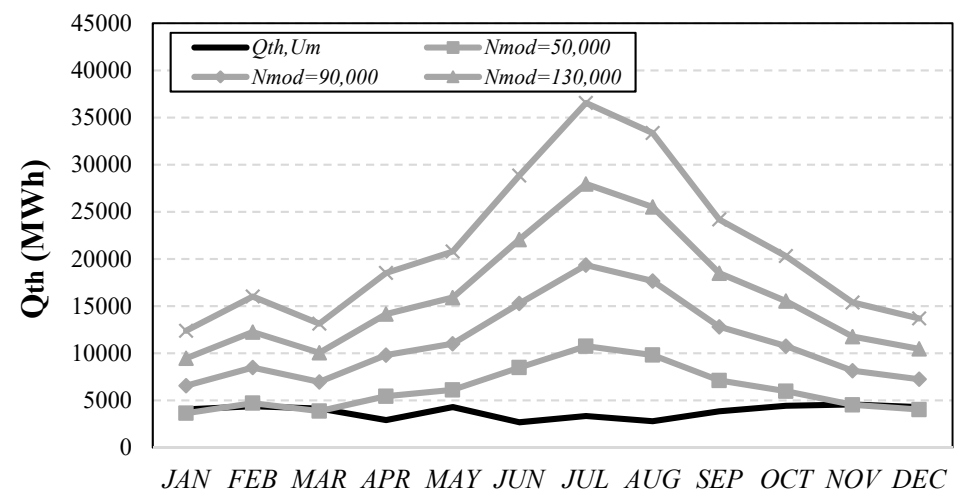

(c)

Figure 5. Difference between the CPV/T system thermal outputs on a monthly basis by varying its number of modules and the thermal loads of the three users: (a) house; (b) hotel; and(c) industry.

In Figure 6, the trends of the annual electrical energy used and sold by varying the number of modules for the three users defined are shown. It is evident that by increasing 
the modules number, the shares of the user energy needs satisfied by means of the CPV/T increase to satisfy all the energy requirements [27]. A further increase of the CPV/T system size leads to an increase of the only electrical energy sold to the energy network, which represents overproduction with respect to energy needs.

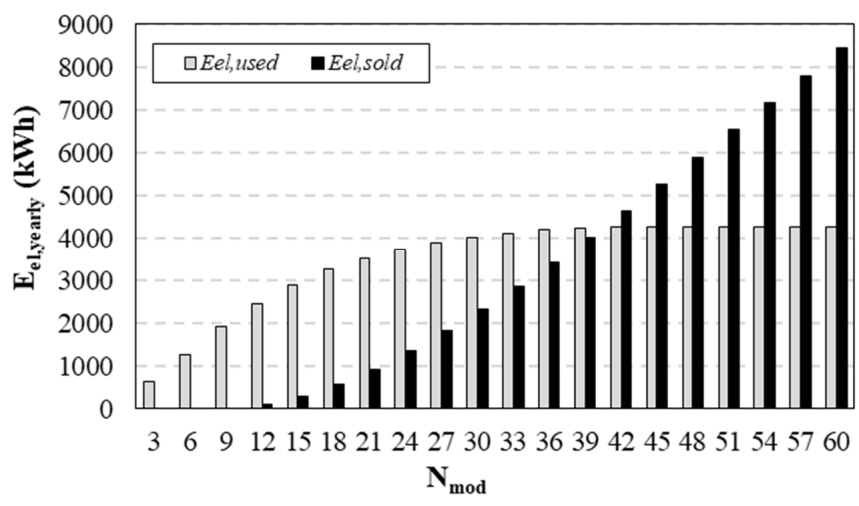

(a)

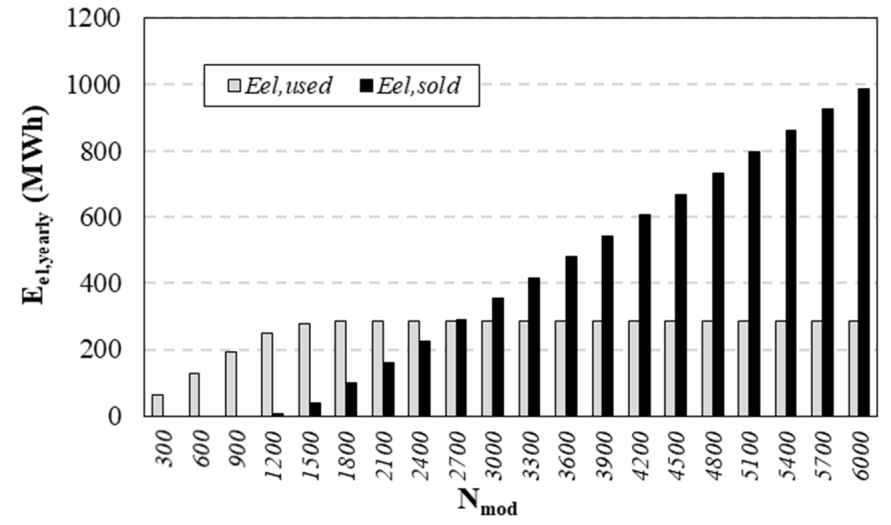

(b)

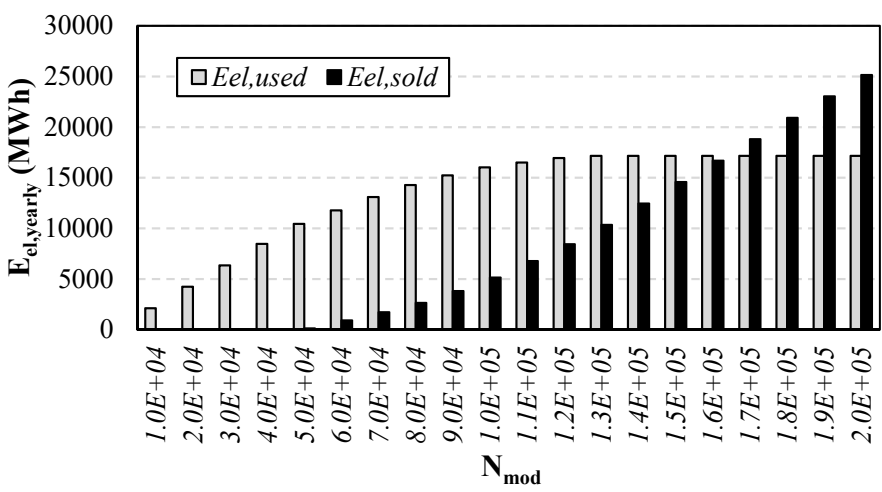

(c)

Figure 6. Trends of the annual electrical energy used and sold by varying the number of modules for the three users: (a) house; (b) hotel; and (c) industry.

As stated in the previous section, the optimal number of modules for each user can be calculated with the aim of maximizing the profitability of the investment in terms of NPV, calculated by means of Equation (10). The values of all the parameters necessary for this analysis are resumed in Table $4[28,29]$. 
Table 4. Values of the parameters used in the sizing of the CPV/T systems for the three users [28,29].

\begin{tabular}{cccc}
\hline Parameter & House & Hotel & Industry \\
\hline Useful life for a CPV system: UL & 20 years & 20 years & 20 years \\
Cost per unit of power $\left(\mathrm{c}_{\mathrm{u}, \mathrm{P}}\right)$ & $2.88 € / \mathrm{W}$ & $2.13 € / \mathrm{W}$ & $1.07 € / \mathrm{W}$ \\
Purchase cost of electricity: $\mathrm{c}_{\mathrm{el}}$ & $0.231 € / \mathrm{kWh}$ & $0.188 € / \mathrm{kWh}$ & $0.158 € / \mathrm{kWh}$ \\
Electricity selling price: $\mathrm{p}_{\mathrm{e}}$ & $0.038 € / \mathrm{kWh}$ & $0.031 € / \mathrm{kWh}$ & $0.026 € / \mathrm{kWh}$ \\
Thermal energy cost: $\mathrm{c}_{\text {th }}$ & $0.095 € / \mathrm{kWh}$ & $0.060 € / \mathrm{kWh}$ & $0.032 € / \mathrm{kWh}$ \\
Discount index: $\mathrm{r}$ & 0.015 & 0.015 & 0.015 \\
\hline
\end{tabular}

The calculated NPVs at the 20th year, average useful life for a CPV system, as a function of the number of modules are shown in Figure 7, together with the area required. It can be noted that, for each user, the NPV increases with the number of modules until it reaches its maximum value. A further increase in the CPV system size leads to a surplus electrical energy which is to be sold to the energy network at a price much lower than the purchase price, thus reducing cash flows. Moreover, an oversized system leads to a surplus of thermal energy, which constitute a loss. Hence, the optimal number of modules is 36 for the domestic user, with an NPV equal to $28.1 \mathrm{k} €$ and a necessary area of $43.2 \mathrm{~m}^{2}$; the optimal number of modules is 1500 modules for the hotel, with an NPV of $1237 \mathrm{k} €$ and an area of $1800 \mathrm{~m}^{2}$. The optimal number of modules is 130,000 for the industry, with an NPV of about $60,000 \mathrm{k} €$ and an area of $156,000 \mathrm{~m}^{2}$.

The NPV trends over the years in correspondence of the optimal number of modules for each user are shown in Figure 8. These trends allow evaluating the DPBP of the investment, which is equal to 6 years for the domestic user and are equal to about 5 and 4 for the hotel and the industry, respectively. The PIs are equal to $224 \%$ for the domestic user, $320 \%$ for the hotel, and $355 \%$ for the industrial user.

The economic analysis performed refers to the current costs of CPV systems. However, as reported above, because of the forecasted increase of the $\mathrm{CPV}$ power capacity $\left(\mathrm{PC}_{\mathrm{CPV}}\right)$, a cost decrease of this technology is to be expected in the next years [19-30]. Hence, by relating the CPV cost reduction over years reported in Table 2 with the CPV power capacity $\left(\mathrm{PC}_{\mathrm{CPV}}\right.$ ) per year in Figure 2, it is possible to plot the trends shown in Figure 9 for the four categories previously defined. As shown in Figure 9, the high increase of the CPV power capacity during the years from 2011 to 2019 leads to a reduction in their unit cost of electrical power, which can be described by means of Equation (9). The values of coefficients $\gamma$ and $\delta$ in Equation (9) are reported in Table 5 for each category defined of the CPV system, together with the values of $R^{2}$.

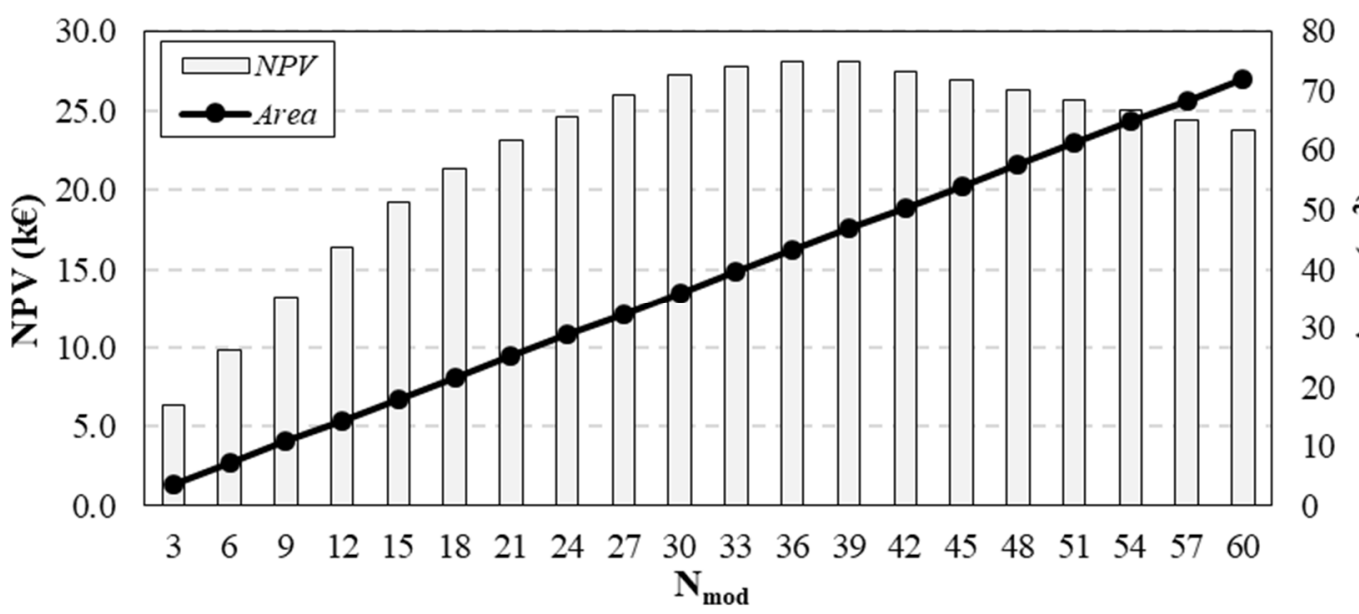

(a)

Figure 7. Cont. 


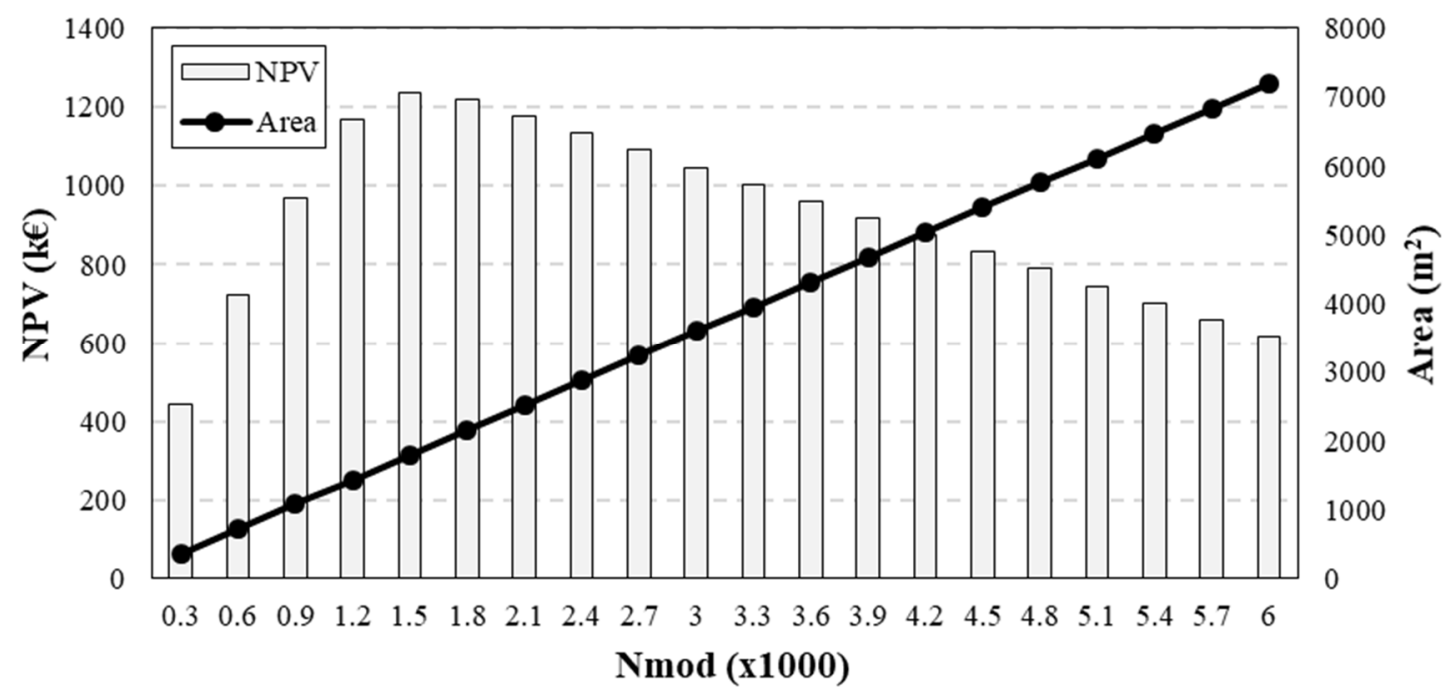

(b)

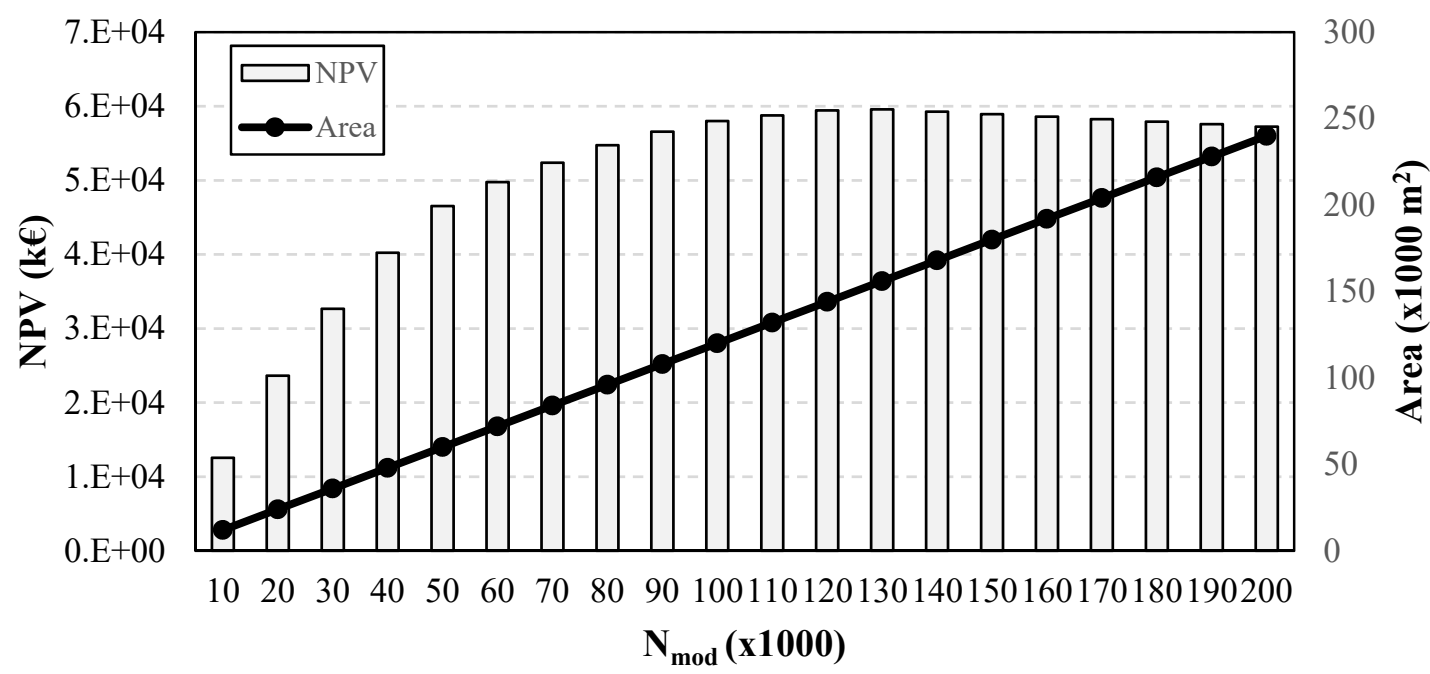

(c)

Figure 7. Net present values (NPVs) at the 20th year by varying number of modules for the three users defined: (a) house; (b) hotel; and(c) industry. 


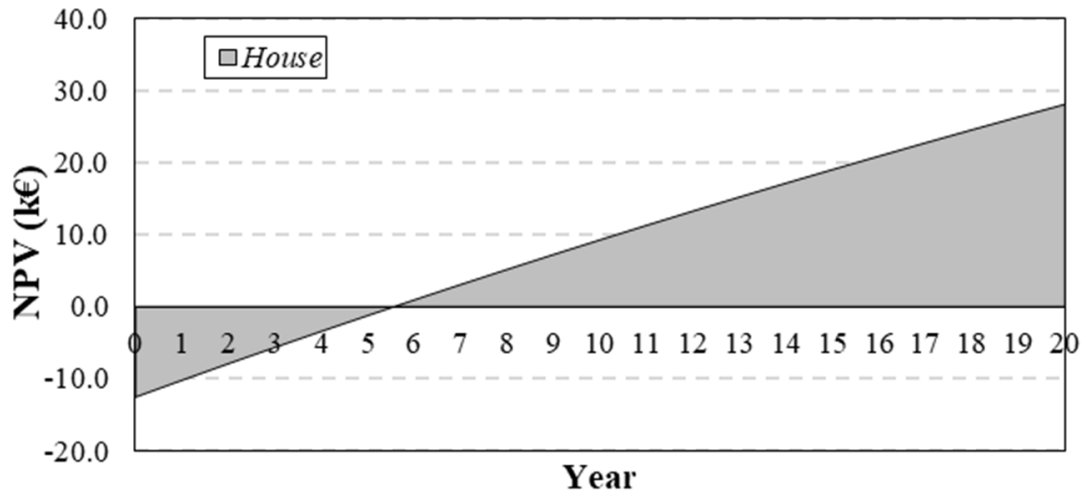

(a)

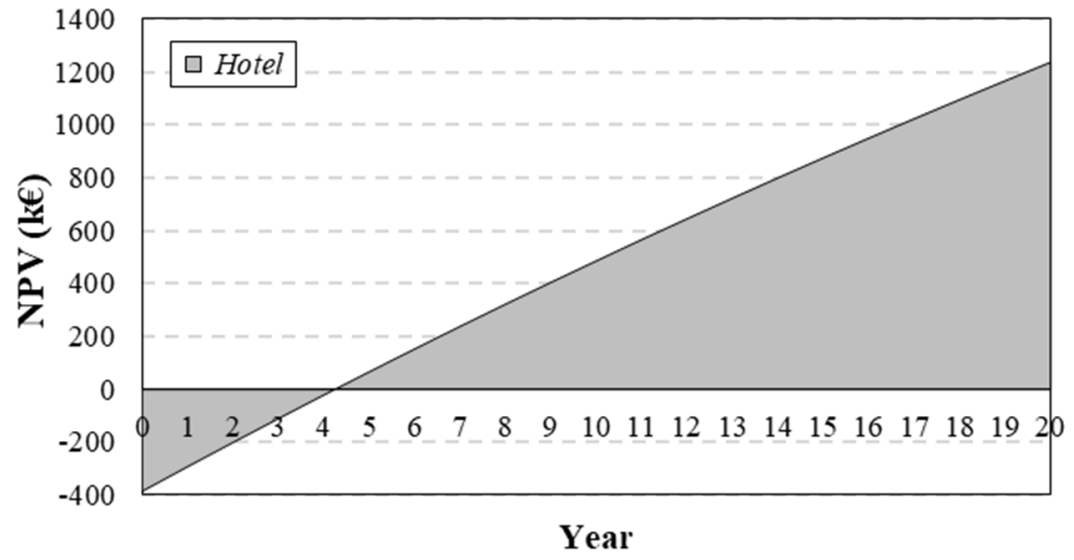

(b)

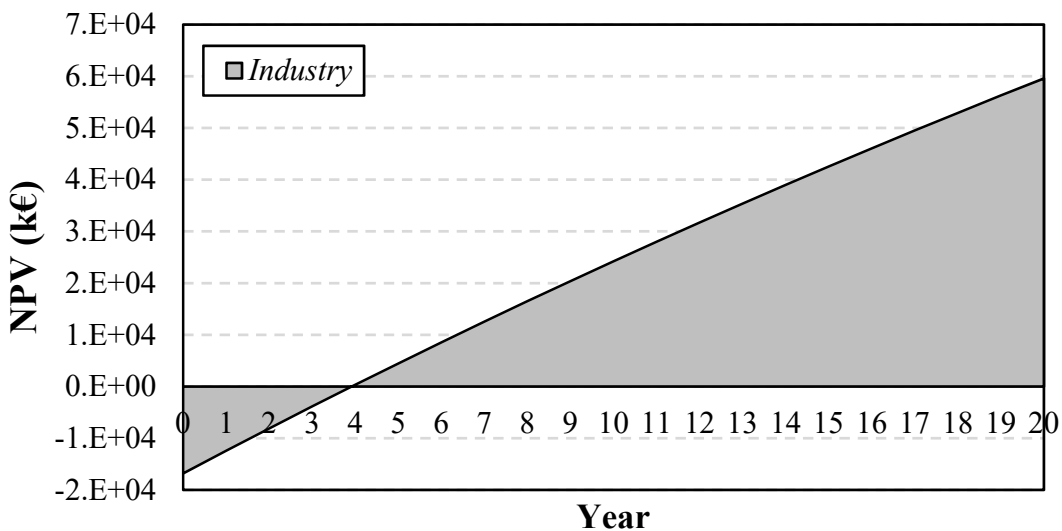

(c)

Figure 8. NPV trends over the years in correspondence of the optimal number of modules for the three users defined: (a) house; (b) hotel; and (c) industry. 


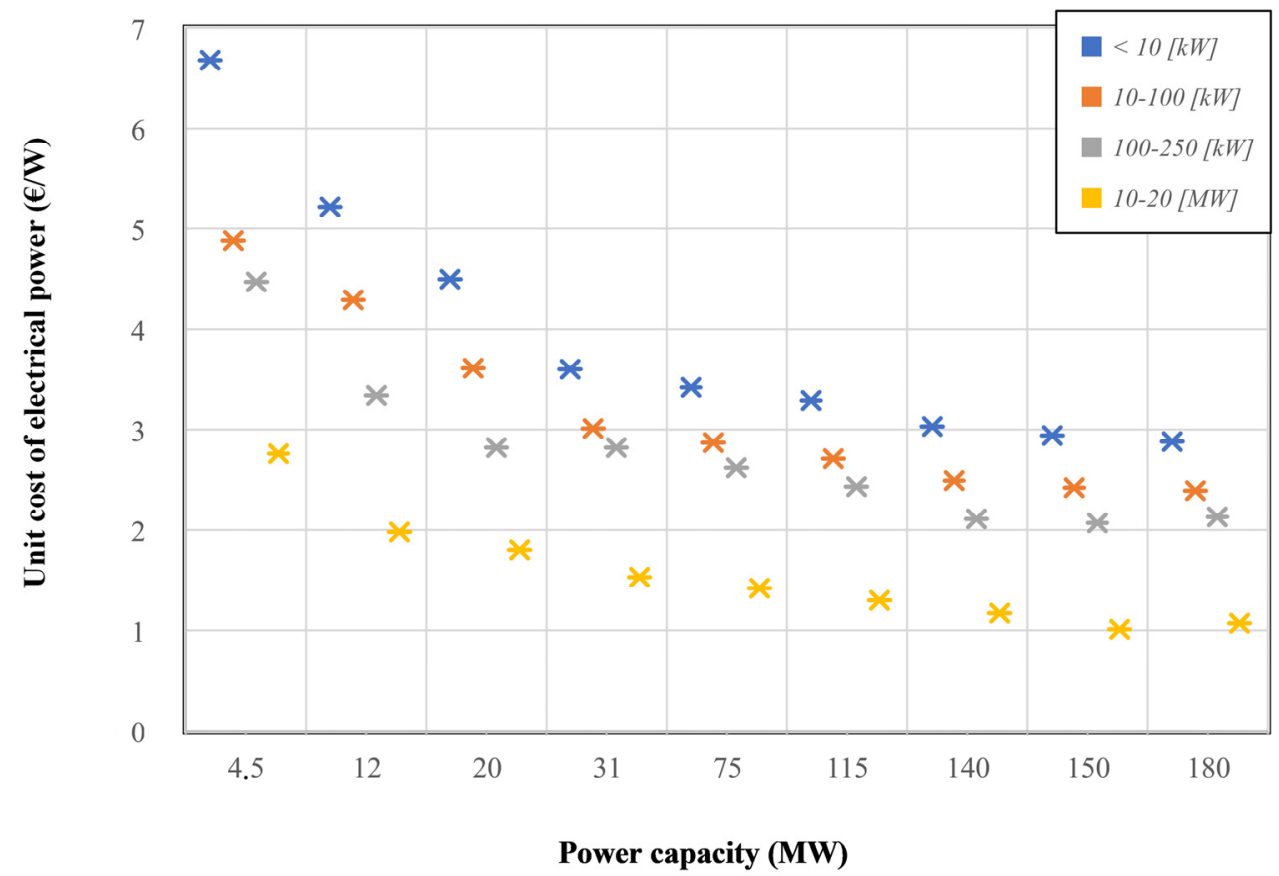

Figure 9. Unit costs of the electric power supplied by a CPV system in terms of the CPV system power capacity for the four categories.

Table 5. Coefficients values of the equation describing the trends of the unit cost of the electric power supplied by a CPV system as a function of the CPV power capacity for the four categories defined.

\begin{tabular}{cccc}
\hline CPV Category & $\gamma$ & $\delta$ & $\mathbf{R}^{2}$ \\
\hline$<10 \mathrm{~kW}$ & 8.78 & -0.218 & 0.956 \\
$10-100 \mathrm{~kW}$ & 6.54 & -0.195 & 0.966 \\
$100-250 \mathrm{~kW}$ & 5.47 & -0.186 & 0.937 \\
$10-20 \mathrm{MW}$ & 3.78 & -0.243 & 0.961 \\
\hline
\end{tabular}

These trends can be extrapolated to forecast the values of $c_{u, P}$ till the year 2025 in both an optimistic scenario and a pessimistic scenario, as reported in Table 6. The results show that the costs of the CPV systems could decrease up to $30 \%$ in 2025 in an optimistic scenario.

Table 6. Forecasted values of $c_{u, P}$ till the year 2025 in both an optimistic scenario and a pessimistic scenario.

\begin{tabular}{ccccccccc}
\hline & \multicolumn{2}{c}{$<\mathbf{1 0}(\mathbf{k W})$} & \multicolumn{10}{c}{$\mathbf{1 0 0}(\mathbf{k W})$} & $\mathbf{1 0 0 - 2 5 0} \mathbf{( k W )}$ & $\mathbf{1 0 - 2 0}(\mathbf{M W})$ \\
\hline Year & $\begin{array}{c}\text { Pessimistic } \\
\text { (Pes.) }\end{array}$ & $\begin{array}{c}\text { Optimistic } \\
\text { (Opt.) }\end{array}$ & Pes. & Opt. & Pes. & Opt. & Pes. & Opt. \\
\hline 2020 & 2.77 & 2.64 & 2.33 & 2.23 & 2.04 & 1.96 & 1.04 & 0.99 \\
2021 & 2.70 & 2.53 & 2.27 & 2.15 & 2.00 & 1.89 & 1.01 & 0.95 \\
2022 & 2.64 & 2.38 & 2.23 & 2.03 & 1.96 & 1.79 & 0.99 & 0.88 \\
2023 & 2.58 & 2.24 & 2.19 & 1.93 & 1.92 & 1.71 & 0.97 & 0.83 \\
2024 & 2.53 & 2.14 & 2.15 & 1.85 & 1.89 & 1.64 & 0.95 & 0.78 \\
2025 & 2.45 & 2.05 & 2.09 & 1.78 & 1.84 & 1.58 & 0.91 & 0.75 \\
\hline
\end{tabular}

Considering the values of $\mathrm{c}_{\mathrm{u}, \mathrm{P}}$ reported in Table 6 , it is possible to analyze the variation of the economic performances of a CPV system applied to the three users defined in the present study between the present and 2025 in the two scenarios-optimistic and pessimistic scenarios (Table 6).

As shown, according to the cost forecasts, CPV systems will become more convenient in 2025. In fact, for the CPV systems adopted for the residential user (Figure 10a), the 
NPV will increase from $28.1 \mathrm{k} €$ to $30.0 \mathrm{k} €$ in a pessimistic scenario and to $31.7 \mathrm{k} €$ in an optimistic scenario, while the DPBP will decrease from 5.6 years to 4.7 and 3.9 years in a pessimistic scenario and an optimistic scenario, respectively. As for the hotel (Figure 10b), the NPV will increase from $1237 \mathrm{k} €$ to $1289 \mathrm{k} €$ in a pessimistic scenario and to $1337 \mathrm{k} €$ in an optimistic scenario, while the DPBP will decrease from 4.2 years to 3.7 and 3.1 years in a pessimistic scenario and an optimistic scenario, respectively. Finally, as for the industrial user (Figure 10c), the NPV will increase from 59,578 $\mathrm{k} €$ to $62,090 \mathrm{k} €$ in a pessimistic scenario and to $64,603 \mathrm{k} €$ in an optimistic scenario, while the DPBP will decrease from 3.9 years to 3.3 and 2.7 years in a pessimistic scenario and an optimistic scenario, respectively.

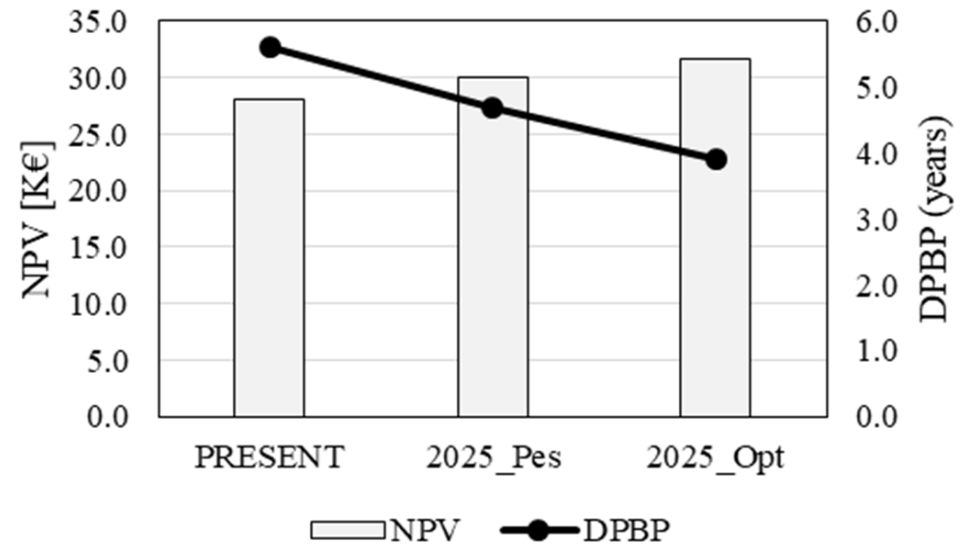

(a)

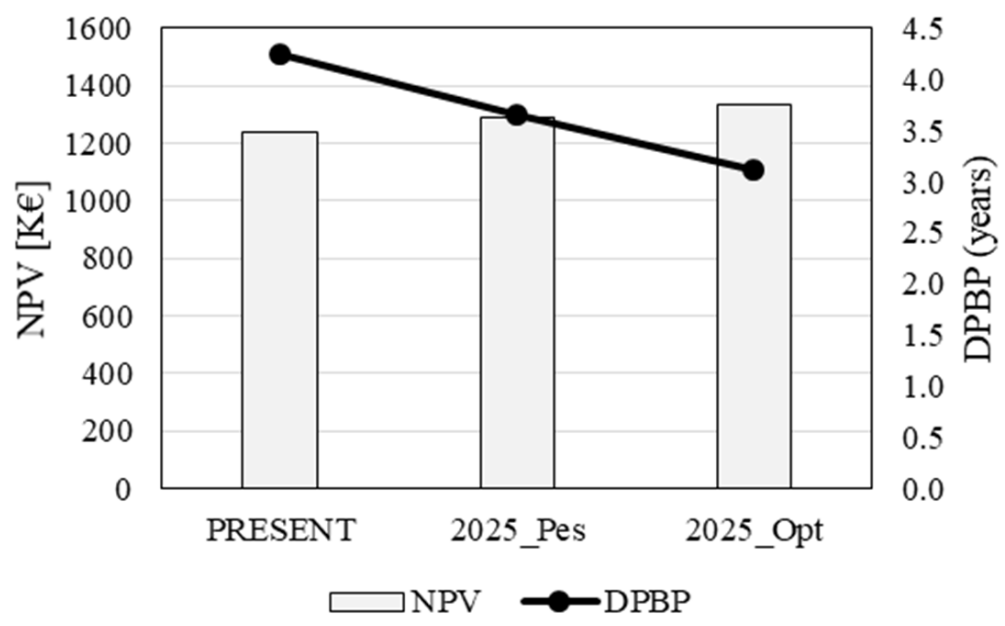

(b)

Figure 10. Cont. 


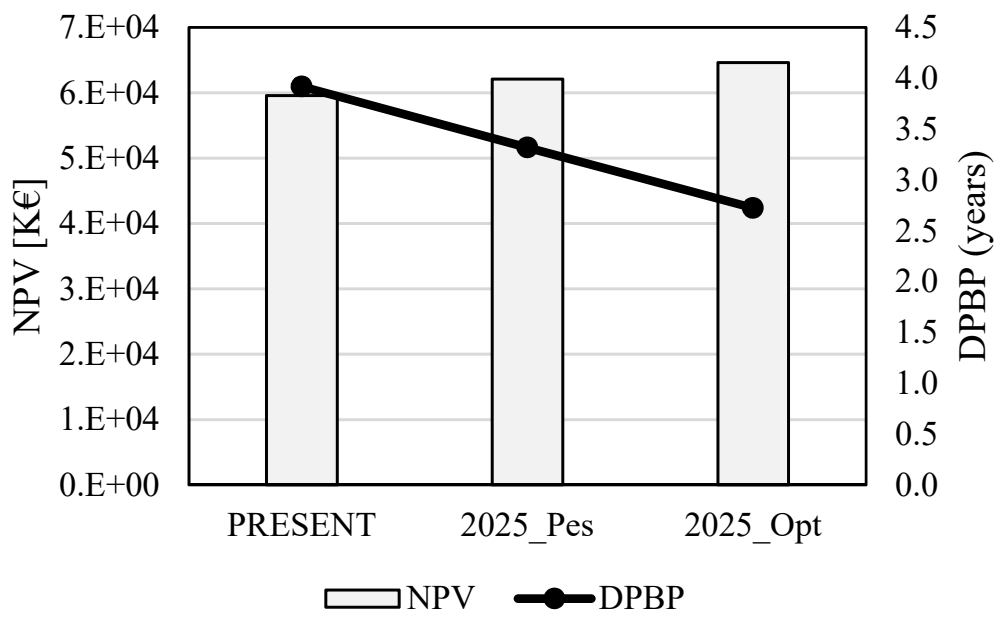

(c)

Figure 10. NPV and discounted payback period (DPBP) variations between the present and 2025 in optimistic and pessimistic scenarios for CPV systems adopted for the three users: (a) house; (b) hotel; and (c) industry.

\section{Conclusions}

The aim of the paper is to analyze the feasibility of a CPV / T system used for users with increasing size. Three users located in Salerno (Italy) have been defined: the house as a small-size user, the hotel as a middle-size user, and the food industry as a large-size user. For the CPV/T system, the experimental plant described, with optical concentration factors equal to 90 and an amount of 60 cells, has been considered as a single module. An experimental model has been used for an accurate evaluation of the electrical and thermal powers supplied by the CPV systems when DNI and $\mathrm{T}_{\text {env }}$ vary. The difference, on a monthly basis, between the CPV/T system outputs and the energy loads of each user when its number of modules varies, has been analyzed. Since the house and the food industry present an almost constant monthly electrical load during the year, the $\mathrm{CPV} / \mathrm{T}$ system producibility exceeds the user needs in the summer period. On the other hand, the hotel presents a greater variability in its monthly energy needs, and the CPV/T system electrical producibility better fits the user monthly loads. From a thermal point of view, in correspondence of the modules number considered, the CPV / T system thermal producibility exceeds the loads of each user almost all over the year. The annual electrical energy trends used and sold by varying the modules number for the three users defined have been analyzed. The NPV trend as a function of the modules number has been analyzed, thus determining the optimal number of modules for each user. The optimal number of modules is 36 for the domestic user, with an NPV equal to $28.1 \mathrm{k} €$, a DPBP of 5.6 years, a PI of $224 \%$, and a necessary area of $43.2 \mathrm{~m}^{2}$. The optimal number of modules is 1500 for the hotel, with an NPV of $1237 \mathrm{k} €$, a DPBP of 4.2 years, a PI of $320 \%$, and an area of $1800 \mathrm{~m}^{2}$. The optimal number of modules is 130,000 for the industry with an NPV of about $60,000 \mathrm{k} €$, a DPBP of 3.9 years, a PI of $355 \%$, and an area of $156,000 \mathrm{~m}^{2}$. The economic results obtained are expected to get better in the next years. In fact, by analyzing the cost reduction of the CPV system for the last years, a forecast till the year 2025 in both optimistic and pessimistic scenarios has been performed. The results have shown that CPV systems will become more convenient in next years. In 2025, for the same CPV system adopted for the domestic user, the NPVs are expected to increase by about $6.7 \%$ and $13 \%$ in pessimistic and optimistic scenarios, respectively, with reductions of its DPBP of $16 \%$ and $30 \%$. As for the other two users, the NPVs are expected to increase by about $4.2 \%$ and $8.4 \%$ in pessimistic and optimistic scenarios, respectively, with decreases of its DPBP by $14 \%$ and $27 \%$. 
Author Contributions: Conceptualization, C.R., A.P., D.D. and F.M.; data curation, C.R., A.P., D.D. and F.M.; formal Analysis, C.R., A.P., D.D. and F.M.; funding acquisition, C.R.; investigation, C.R., A.P., D.D. and F.M.; methodology, C.R., A.P., D.D. and F.M.; project administration, C.R.; resources, C.R.; supervision, C.R.; validation, C.R., A.P., D.D. and F.M.; visualization, C.R.; writing of the original draft preparation, C.R., A.P., D.D. and F.M.; writing of review and editing, C.R., A.P., D.D. and F.M. All authors have read and agreed to the published version of the manuscript.

Funding: The research received no external funding.

Conflicts of Interest: The author declares no conflict of interest.

\begin{tabular}{|c|c|}
\hline Abbreviations & \\
\hline A & area $\left(\mathrm{m}^{2}\right)$ \\
\hline $\mathrm{c}_{\mathrm{el}}$ & cost of electrical energy per unit purchase $(€ / \mathrm{kWh})$ \\
\hline$c_{\text {mod }}$ & cost per module $(€ / \mathrm{mod})$ \\
\hline$c_{\text {th }}$ & cost of thermal energy per unit purchase $(€ / \mathrm{kWh})$ \\
\hline CF & cash flow $(€ /$ year $)$ \\
\hline $\mathrm{C}_{\text {opt }}$ & optical concentration ratio \\
\hline CPV & concentrating photovoltaic system \\
\hline $\mathrm{CPV} / \mathrm{T}$ & concentrating photovoltaic and thermal system \\
\hline CS & cost saving $(€ /$ year $)$ \\
\hline DNI & direct normal irradiance $\left(\mathrm{kW} / \mathrm{m}^{2}\right)$ \\
\hline DPBP & discount payback period \\
\hline $\mathrm{E}$ & energy \\
\hline f & non-ideal tracking system factor \\
\hline G & gains from the sale of the surplus energy ( $€ /$ year) \\
\hline $\mathrm{I}_{0}$ & initial investment $(€)$ \\
\hline $\mathrm{InGaP} / \mathrm{GaAs} / \mathrm{Ge}$ & indium gallium phosphate/gallium arsenide/germanium \\
\hline LT & low temperature \\
\hline MHT & middle-high temperature \\
\hline MPPT & maximum power point tracking \\
\hline $\mathrm{n}$ & number \\
\hline NPV & net present value $(€)$ \\
\hline $\mathrm{P}$ & electric power $(\mathrm{W})$ \\
\hline $\mathrm{p}_{\mathrm{e}}$ & electrical energy selling price to the energy network \\
\hline PI & profit index \\
\hline Q & thermal power $(\mathrm{W})$ \\
\hline $\mathrm{r}$ & discount rate \\
\hline$S_{\text {cell }}$ & concentrated solar radiation incident on the TJ cell $\left(\mathrm{kW} / \mathrm{m}^{2}\right)$ \\
\hline $\mathrm{T}$ & temperature $\left({ }^{\circ} \mathrm{C}\right)$ \\
\hline TJ & triple-junction cell \\
\hline UL & CPV system useful life (years) \\
\hline$\eta$ & efficiency \\
\hline Subscripts & \\
\hline c & cell \\
\hline el & electrical \\
\hline env & environmental \\
\hline inv & inverter \\
\hline loss & losses \\
\hline $\mathrm{m}$ & monthly \\
\hline $\bmod$ & module \\
\hline opt & optical \\
\hline th & thermal \\
\hline tube & coolant flow tube \\
\hline $\mathrm{U}$ & user \\
\hline
\end{tabular}




\section{References}

1. Rejeb, O.; Shittu, S.; Ghenai, C.; Li, G.; Zhao, X.; Bettayeb, M. Optimization and performance analysis of a solar concentrated photovoltaic-thermoelectric (CPV-TE) hybrid system. Renew. Energy 2020, 152, 1342-1353. [CrossRef]

2. Burhan, M.; Shahzad, M.W.; Oh, S.J.; Ng, K.C. Long Term Electrical Rating of Concentrated Photovoltaic (CPV) Systems in Singapore. Energy Procedia 2019, 158, 73-78. [CrossRef]

3. Renno, C. Theoretical and experimental evaluation of the working fluid temperature levels in a CPV/T system. Energies 2020, 13, 3077. [CrossRef]

4. Murugan, S.; Horák, B. Tri and polygeneration systems-A review. Renew. Sustain. Energy Rev. 2016, 60, 1032-1051. [CrossRef]

5. D'Agostino, D.; Marino, C.; Minichiello, F.; Russo, F. Obtaining a NZEB in Mediterranean climate by using only on-site renewable energy: Is it a realistic goal? Energy Procedia 2017, 140, 23-35. [CrossRef]

6. Chen, S.X.; Gooi, H.B.; Wang, M.Q. Solar radiation forecast based on fuzzy logic and neural networks. Renew. Energy 2013, 60, 195-201. [CrossRef]

7. Soni, M.S.; Gakkhar, N. Techno-economic parametric assessment of solar power in India: A survey. Renew. Sustain. Energy Rev. 2014, 40, 326-334. [CrossRef]

8. Kannan, N.; Vakeesan, D. Solar energy for future world-A review. Renew. Sustain. Energy Rev. 2016, 62, 1092-1105. [CrossRef]

9. Wang, G.; Chen, Z.; Hu, P.; Cheng, X. Design and optical analysis of the band-focus Fresnel lens solar concentrator. Appl. Therm. Eng. 2016, 102, 695-700. [CrossRef]

10. Bellos, E.; Tzivanidis, C.; Antonopoulos, K.A.; Gkinis, G. Thermal enhancement of solar parabolic trough collectors by using nanofluids and converging-diverging absorber tube. Renew. Energy 2016, 94, 213-222. [CrossRef]

11. Wang, G.; Yao, Y.; Chen, Z.; Hu, P. Thermodynamic and optical analyses of a hybrid solar CPV/T system with high solar concentrating uniformity based on spectral beam splitting technology. Energy 2019, 166, 256-266. [CrossRef]

12. Renno, C. Optimization of a concentrating photovoltaic thermal (CPV/T) system used for a domestic application. Appl. Therm. Eng. 2014, 67, 396-408. [CrossRef]

13. Garcia-Domingo, B.; Piliougine, M.; Elizondo, D.; Aguilera, J. CPV module electric characterisation by artificial neural networks. Renew. Energy 2015, 78, 173-181. [CrossRef]

14. Renno, C. Experimental and Theoretical Analysis of a Linear Focus CPV/T System for Cogeneration Purposes. Energies 2018, 11, 2960. [CrossRef]

15. Xu, N.; Ji, J.; Sun, W.; Han, L.; Chen, H.; Jin, Z. Outdoor performance analysis of a $1090 \times$ point-focus Fresnel high concentrator photovoltaic/thermal system with triple-junction solar cells. Energy Convers. Manag. 2015, 100, 191-200. [CrossRef]

16. Radwan, A.; Ookawara, S.; Ahmed, M. Analysis and simulation of concentrating photovoltaic systems with a microchannel heat sink. Sol. Energy 2016, 136, 35-48. [CrossRef]

17. De Negri, J.F.; Pezzutto, S.; Gantioler, S.; Moser, D.; Sparber, W. A Comprehensive Analysis of Public and Private Funding for Photovoltaics Research and Development in the European Union, Norway, and Turkey. Energies 2020, 13, 2743. [CrossRef]

18. Fraunhofer Institute for Solar Energy Systems, ISE, with Support of PSE Conferences \& Consulting GmbH "Photovoltaics Report", 27 August 2018. Available online: http:/ / cetcsolarenergy.com/downloads/Fraunhofer_ISE_Photovoltaics_Report_2018.pdf (accessed on 23 September 2020).

19. Francesca Tilli-GSE/Giosuè Maugeri-RSE, National Survey Report of PV Power Applications in Italy-2018. Available online: https:/ /iea-pvps.org/wp-content/uploads/2020/01/NSR_Italy_2018.pdf (accessed on 23 September 2020).

20. Renno, C.; Petito, F.; Landi, G.; Neitzert, H.C. Experimental characterization of a concentrating photovoltaic system varying the light concentration. Energy Convers. Manag. 2017, 138, 119-130. [CrossRef]

21. Georgescu-Roegen, N. Energy Analysis and Economic Valuation. South. Econ. J. 1979, XLIV, 1023-1058. [CrossRef]

22. Yazdanifard, F.; Ebrahimnia-Bajestan, E.; Ameri, M. Performance of a parabolic trough concentrating photovoltaic/thermal system: Effects of flow regime, design parameters, and using nanofluids. Energy Convers. Manag. 2017, 148, 1265-1277. [CrossRef]

23. Renno, C.; Petito, F. Triple-junction cell temperature evaluation in a CPV system by means of a Random-Forest model. Energy Convers. Manag. 2018, 169, 124-136. [CrossRef]

24. Renno, C.; Perone, A. Experimental modeling of the optical and energy performances of a point-focus CPV system applied to a residential user. Energy 2021, 215, 326-340. [CrossRef]

25. PVGIS. Available online: https://re.jrc.ec.europa.eu/pvg_tools/en/tools.html\#MR (accessed on 23 September 2020).

26. Renno, C.; Landi, G.; Petito, F.; Neitzert, H.C. Influence of a degraded triple-junction solar cell on the CPV system performances. Energy Convers. Manag. 2018, 160, 326-340. [CrossRef]

27. Aprea, C.; Renno, C. Experimental model of a variable capacity compressor. Int. J. Energy Res. 2009, 33, 29-37. [CrossRef]

28. Electricity Price Statistics/It. Available online: https:/ / ec.europa.eu/eurostat/statistics-explained/index.php?title=Electricity_ price_statistics/it (accessed on 23 September 2020).

29. Natural Gas Price Statistics. Available online: https:/ / ec.europa.eu/eurostat/statistics-explained/index.php?title=Natural_gas_ price_statistics (accessed on 23 September 2020).

30. Renno, C.; D'Agostino, D.; Minichiello, F.; Petito, F.; Balen, I. Performance analysis of a CPV/T-DC integrated system adopted for the energy requirements of a supermarket. Appl. Therm. Eng. 2019, 149, 231-248. [CrossRef] 